DOI https://doi.org/10.30525/978-9934-26-075-9-47

\title{
ЗНАЧЕННЯ ПРЕНАТАЛЬНОЇ І НЕОНАТАЛЬНОЇ ДІАГНОСТИКИ У ПРОФІЛАКТИЦІ СПАДКОВОЇ ПАТОЛОГІї У ЛЮДИНИ
}

\author{
Шевчук T. I. \\ кандидат медичних наук, \\ доиент кафедри медичної біології
}

Вінницький національний медичний університет імені М. I. Пирогова

Васенко Т. Б.

асистент кафедри медичної біології

Вінницький національний медччний університет імені М. І. Пирогова

Горбатюк С. М.

кандидат біологічних наук,

дочент кафедри медичної біології

Вінницький національний медичний університет імені М. І. Пирогова

\begin{abstract}
Климчук I. М.
асистент кафедри медичної біології

Вінницький національний медичний університет імені М. І. Пирогова м. Вінниця, Украӥна
\end{abstract}

Спадковими називають хвороби, причиною яких є зміна спадкового матеріалу. Генетична нестабільність у вигляді генних, хромосомних і геномних мутацій вносить суттєвий вклад в етіологію розвитку спадкової патології [7, с. 4]. Мутації $\epsilon$ причиною молекулярних (фенілкетонурія, альбінізм, муковісцидоз, таласемія та ін.) і хромосомних (синдром Дауна, синдром Патау, синдром Шерешевського-Тернера та ін.) хвороб [2, с. 173].

Мутаційний процес в еволюційно-генетичному аспекті проявляється у вигляді генетичного поліморфізму людини, який є основою розвитку людини як біологічного виду. Також ефектом мутаційного тягара популяції є летальність, яка проявляється загибеллю гамет, зигот, ембріонів, плодів, дітей і дорослих.

Наслідками мутаційного процесу в медичному аспекті $є$ соціальна дезадаптація хворих, підвищена потреба в медичній допомозі, зниження 
тривалості життя. Зростання частки спадкової патології в популяції людини має не лише медичні і психологічні наслідки, а й соціальні. Тому профілактика генетичних хвороб займає чільне місце в діяльності лікаря і системі охорони здоров'я загалом.

Дослідження, проведені в різних країнах, свідчать про відмінності поширеності певних спадкових хвороб, що можна пояснити різним генетичним тягарем популяцій, генетично-демографічними процесами, а також різним ступенем розвитку діагностичних i профілактичних заходів. Але в структурі загальної захворюваності населення спадкова патологія може сягати 3-7 \% [1, с. 220].

Розрізняють кілька видів профілактики. Первинна профілактика направлена на попередження зачаття хворої дитини і передбачає планування дітонародження і покращення середовища існування людини. Переривання вагітності, як спосіб попередження народження хворої дитини, застосовується при високій ймовірності захворювання у плода або при пренатально діагностованій патології, і відноситься до вторинної профілактики. Третинна профілактика передбачає попередження прояву спадкової патології шляхом корекції хвороби і досягнення нормокопіювання. Тобто профілактика спадкових хвороб відбувається в кілька етапів і проводиться на рівні популяції.

Залежно від стадії онтогенезу людини профілактика може бути преконцепційною, яка направлена на зниження ризику зачаття хворої дитини і дає можливість батькам на основі отриманої інформації свідомо приймати рішення про дітонародження. Пренатальна профілактика передбачає відбір вагітних з ризиком народження хворої дитини з метою уточнення діагнозу у плода, раннього початку пренатального або неонатального лікування, або переривання вагітності [3, с. 721]. Неонатальна профілактика має за мету виявлення хворих серед новонароджених для того, щоб чим раніше почати лікування [4, с. 7]. Неонатальна смертність новонароджених першого року життя в Україні у 2,5-3 рази вищий, ніж у країнах Європи. Одним із ефективних методів зниження ранньої дитячої смертності $є$ впровадження масового скринінгу новонароджених для виявлення спадкових хвороб. Неонатальний скринінг полягає у застосуванні біохімічних методів і визначення у біологічних рідинах певних речовин, концентрація яких буде свідчити про певне захворювання. В Україні проводиться масовий скринінг новонароджених для таких хвороб: фенілкетонурії, вродженого гіпотиреозу, адреногенітального синдрому та муковісцидозу [6, с. 5].

Пренатальна діагностика $€$ частиною медико-генетичного консультування і моніторингу за станом плода і має на меті виявлення групи 
ризику серед вагітних з можливою патологією плода, а також дозволяє точно встановити пренатальний діагноз 3 подальшим вибором тактики ведення вагітності і пологів, можливим призначенням пренатального або неонатального лікування. Пренатальна діагностика включає неінвазивні та інвазивні методи. До неінвазивних методів відноситься скринінгове ультразвукове дослідження, яке проводять всім вагітним. Дане дослідження дозволяє виявити певні морфологічні відхилення у розвитку плода (порушення нервової системи, вроджені вади розвитку органів i систем, хромосомні аномалії).

До неінвазивних методів пренатальної діагностики відноситься біохімічний скринінг вагітних, який також проводять всім вагітним. Він базується на визначенні в крові жінки рівня певних біохімічних маркерів: a-фетопротеїну, $\beta$-частинок хоріонічного гонадотропіна, вільного естріолу і асоційованого 3 вагітністю протеїну А. Діагностична цінність біохімічного скринінгу становить 75-80 \% і виявляє вагітних 3 високим ризиком народження дитини 3 хромосомною аномалією або порушенням розвитку нервової трубки [8, с. 55]. Пренатальний біохімічний скринінг дозволяє визначити, чи відноситься вагітна до групи ризику щодо народження анеуплоїдного плода, а також обгрунтувати подальші інвазивні втручання для точної діагностики. Перевагами неінвазивного скринінгу є відсутність травмування тканин матері і плода i, відповідно, зниження ризику виникнення ускладнень від інвазивних методів. Але недоліками $\epsilon$ наявність псевдонегативних результатів (12-23 \%) або псевдопозитивних (1,9-5,0 \%). Тому біохімічний скринінг повинен доповнюватися іншими методами: визначення позаклітинної ДНК плода або аналіз ДНК, вилученої із застосуванням інвазивних методик [9, с. 48].

Біохімічний скринінг проводиться у першому і другому триместрах вагітності. Скринінг першого триместру розділяє пацієнток на групи низького, середнього i високого ризику. Група низького ризику не підлягає подальшому тестуванню. Групі високого ризику відразу пропонують подальші діагностичні уточнюючі процедури. Групі середнього ризику проводять повторний скринінг в другому триместрі. До основних чотирьох біохімічних маркерів додається ще п’ятий гіпергліколізований хоріонічний гонадотропін [10].

Джерелом позаклітинної ДНК плода $є$ апоптотичні клітини плаценти, які проникають у кровотік матері. Підвищення рівня позаклітинної ДНК плода дозволяє діагностувати хромосомні аномалії, генні хвороби, деякі патології вагітності (мимовільні викидні, гестози, передчасні пологи), а також порушення метаболічного статусу у плода. Але неінвазивне 
тестування є непрямим методом і потребує використання інвазивних методів, до яких відносять амніоцентез, кордоцентез, хоріонбіопсія, плацентоцентез. Вказані методи інвазивної і неінвазивної діагностики дозволяють виділити нуклеїнові кислоти плода, що дає можливість визначити батьківство на ранніх стадіях вагітності, стать дитини, резусфактор, хромосомні аберації і геномні мутації, аномалії розвитку органів плода, мікроцитогенетичні синдроми, схильність до онкологічних, мультифакторіальних захворювань, мітохондріальні хвороби [5, с. 55].

Отже, пренатальна діагностика - спеціальна галузь медицини, що швидко розвивається і включає в себе комплекс інструментальних досліджень (УЗД), оперативних технік (амніоцентез, кордоцентез, біопсія хоріону або тканин плода) і лабораторних методів (цитогенетичні, біохімічні, молекулярно-генетичні).

\section{Література:}

1. Генетико-епідеміологічне дослідження міського та сільського дитячого населення харківської області на прикладі Зміївського району / Федота О. М. та ін. Украӥнський журнал медицини, біологї та спорту. 2018. Том 3, № 4 (13). C. 220-225. DOI:10.26693/jmbs03.04.220.

2. Гришко Ю.М.. Спадковість як причина і умова розвитку хвороб. Світ медицини і біології. 2016. № 12, (2 (56)). С. 172-176.

3. Дерябина С. С. Неонатальный скрининг: этические вопросы расширения спектра скринируемых заболеваний. Вопросы современной педиатрии. 2015. №14 (6). С. 714-723. doi: 10.15690/vsp.v14i6.1482.

4. Николаева Е.А., Семячкина А.Н. Современные возможности лечения наследственных заболеваний у детей. Рос. Вестн. Перинатол. u neдиатр. 2018. № 63 (4). C. 6-14. DOI: 10.21508/1027-4065-201863-4-6-14.

5. Пренатальная генетическая диагностика: принципы, методы, применение и перспективы / Чернов А. Н. и др. Вестник СурГУ. Медииина. 2020. № 2 (44). С. 54-65. DOI 10.34822/2304-94482020-2-54-65.

6. Практичні кроки щодо удосконалення діагностики спадкових хвороб обміну речовин у новонароджених та дітей старшого віку в Україні / Антіпкін Ю. Г. та ін. Неонатологія, хірургія та перинатальна медицина. 2019. Т. IX, № 1(31). C. 5-15. DOI: https://doi.org/10.24061/ 2413-4260.IX.1.31.2019.1.

7. Спадкова патологія людини і геномна нестабільність / Педан Л. Р. та ін. Довкілля та здоров’я. 2018. № 2 (87). С. 4-9. 
8. Шубина К. А., Шумкова П. В. Пренатальная диагностика. Вестник Совета молодых ученых и специалистов Челябинской области. 2016. № 3 (14), T. 1. C. 54-59.

9. Norwitz ER, Levy B. Noninvasive prenatal testing: the future is now. Rev Obstet Gynecol. 2013. № 6(2). P. 48-62. PMID: 24466384; PMCID: PMC3893900.

10. Gordon S, Langaker MD. Prenatal Genetic Screening. [Updated 2020 May 21]. In: StatPearls [Internet]. Treasure Island (FL): StatPearls Publishing; 2021 Jan-. Available from: https://www.ncbi.nlm.nih.gov/books/NBK557702/. 